\title{
PERANAN LAPORAN KEUANGAN DAN PENILAIAN PRINSIP 5C TERHADAP EFEKTIFITAS PEMBERIAN KREDIT PADA PT. BANK BENGKULU CABANG TAIS
}

\author{
Lidya Lesawati, Ahmad Soleh, Zahrah Indah Ferina \\ Universitas Dehasen Bengkulu \\ Jl. Meranti No.32, Sawah Lebar, Kota Bengkulu \\ zahrah.indahferina@gmail.com
}

\begin{abstract}
PT. Bank Bengkulu of Tais Branch is one of the Local Development Banks that provides working capital and investment loans. Based on these characteristics, this study was conducted based on the results of the financial statement analysis held by the debtor (customer) by the marketing officer and credit officer of PT. Bank Bengkulu of Tais Branch, through financial ratio analysis based on 5 (five) examples of cases of received and rejected Working Capital Loans owned by PT. Bank Bengkulu of Tais Branch from the last three months. The results of the 5C principles of assessment (Character, Capacity, Capital, Collateral, and Condition) owned by the debtor (customer) are based on the initial interviews and follow-up interviews with the debtor (customers) by the marketing and credit officers of PT. Bank Bengkulu of Tais Branch based on 5 (five) examples of cases of working capital loans received and rejected. The purpose of this study is to determine the role of financial statement analysis on the effectiveness of credit lending at PT. Bank Bengkulu of Tais Branch based on financial ratio analysis and to determine the role of 5C principle assessment (Character, Capacity, Capital, Collateral, and Condition) on the effectiveness of credit financing at PT. Bank Bengkulu, Tais Branch. The types of research and data analysis methods that will be carried out in this study are descriptive research with quantitative and qualitative approaches. From the results of this study it was found that the role of financial statement analysis and the assessment of the 5C principle played a significant role in the effectiveness of lending to PT. Bank Bengkulu of Tais Branch. Even though in terms of the debtor's ability to repay (the customer) is still lacking, causing bad credit which is an indicator of evaluating the effectiveness of lending, this is caused more by factors of unpredictable economic conditions and causing public selling and purchasing power decreased.
\end{abstract}

Abstrak: PT. Bank Bengkulu Cabang Tais adalah salah satu Bank Pembangunan Daerah yang menyediakan modal kerja dan pinjaman investasi. Berdasarkan karakteristik tersebut, penelitian ini dilakukan berdasarkan hasil analisis laporan keuangan yang dipegang oleh debitur (pelanggan) oleh petugas pemasaran dan petugas kredit PT. Bank Bengkulu Cabang Tais, melalui analisis rasio keuangan berdasarkan 5 (lima) contoh kasus Kredit Modal Kerja yang diterima dan ditolak yang dimiliki oleh PT. Bank Bengkulu Cabang Tais dari tiga bulan terakhir. Hasil dari prinsip penilaian 5C (Karakter, Kapasitas, Modal, Jaminan, dan Kondisi) yang dimiliki oleh debitur (pelanggan) didasarkan pada wawancara awal dan wawancara lanjutan dengan debitur (pelanggan) oleh petugas pemasaran dan kredit dari PT. Bank Bengkulu Cabang Tais berdasarkan 5 (lima) contoh kasus pinjaman modal kerja yang diterima dan ditolak. Tujuan dari penelitian ini adalah untuk mengetahui peran analisis laporan keuangan terhadap efektivitas pemberian kredit pada PT. Bank 
Bengkulu Cabang Tais berdasarkan analisis rasio keuangan dan untuk mengetahui peran penilaian prinsip 5C (Karakter, Kapasitas, Modal, Jaminan, dan Kondisi) pada efektivitas pembiayaan kredit di PT. Bank Bengkulu, Cabang Tais. Jenis-jenis penelitian dan metode analisis data yang akan dilakukan dalam penelitian ini adalah penelitian deskriptif dengan pendekatan kuantitatif dan kualitatif. Dari hasil penelitian ini ditemukan bahwa peran analisis laporan keuangan dan penilaian prinsip 5C memainkan peran penting dalam efektivitas pemberian pinjaman kepada PT. Bank Bengkulu Cabang Tais. Meskipun dalam hal kemampuan debitur untuk membayar (pelanggan) masih kurang, menyebabkan kredit macet yang merupakan indikator mengevaluasi efektivitas pinjaman, ini lebih disebabkan oleh faktor-faktor kondisi ekonomi yang tidak dapat diprediksi dan menyebabkan penjualan publik dan daya beli menurun. .

Kata Kunci: Laporan Keuangan, Prinsip Penilaian, Pemberian Kredit,

\section{PENDAHULUAN}

Kasmir (2012: 3) berpendapat bahwa bank merupakan lembaga keuangan yang kegiatannya menghimpun dana dari masyarakat dan kemudian menyalurkan kembali ke masyarakat, serta memberikan jasa-jasa bank lainnya. Dari beberapa pengertian bank di atas dapat disimpulkan kalau bank merupakan sarana untuk meningkatkan taraf hidup orang banyak lewat menyalurkan dana kepada masyarakat salah satu nya dalam bentuk pembiayaan kredit. Menurut UU Perbankan Pasal 1 No. 10 tahun 1998 menjelaskan kredit adalah

Pentediaan uang atau tagihan yang dapat dipersamakan dengan itu, berdasarkan persetujuan atau kesepakatan pinjam meminjam antara bank dengan pihak lain yang mewajibkan pihak peminjam melunasi utangnya setelah jangka waktu tertentu dengan pemberian bunga. Kemudian, menurut Hasibuan (2008: 87) kredit adalah semua jenis pinjaman yang harus dibayar kembali bersama bunganya oleh peminjam sesuai dengan perjanjian yang telah disepakati.

Proses pembiayaan kredit tersebut sangat dipengaruhi oleh ketentuan dan kebijakan yang berlaku pada bank itu sendiri. Dengan kata lain sebelum memberikan pembiayaan, pihak bank atau dalam hal ini pimpinan bank diberikan wewenang penuh untuk memutuskan pemberian pembiayaan kredit tersebut layak atau tidak dengan selalu memperhatikan beberapa faktor sebagai bahan pertimbangannya, seperti besarnya jumlah pengajuan pembiayaan kredit yang diminta, tujuan penggunaan dana, kelayakan usaha calon debitur, bentuk dan nilai jaminan yang diberikan, kelengkapan syarat pengajuan kredit dan beberapa pertimbangan lainnya yang diperlukan untuk pembiayaan kredit (Latumena, 2015).

Menurut Kasmir (2010: 115), prosedur pemberian kredit meliputi : pengajuan berkas, penyelidikan berkas pinjaman, wawancara awal, on the spot, wawancara II, keputusan kredit, penanda tanganan akad kredit, dan realisasi kredit. Kegiatan pemberian kredit ini merupakan usaha yang didasarkan pada kepercayaan dan banyak menanggung resiko. Oleh karena itu pengelolaannya harus dilakukan secara profesional dengan dibantu pengawasan dan pengendalian internal yang ketat. 
Nasabah atau calon debitur yang mengajukan kredit wajib melalui tahapan-tahapan prosedur yang telah ditetapkan oleh pihak bank. Tujuan utama dari prosedur ini untuk mempermudah bank menilai kelayakan permohonan kredit. Dalam memutuskan pemberian kredit modal kerja banyak hal-hal yang harus dipertimbangkan oleh pihak bank untuk memanajemen risiko. Supriyono (2011) menjelaskan bahwa sebuah bank dapat jatuh karena Unpredictable Risk, dan sama pula dengan sebuah perusahaan, dapat pailit dan bangkrut karena resiko yang tidak terduga.

Resiko yang tidak terduga tersebut salah satunya seperti pembiayaan bermasalah atau kredit macet. Menurut Ismail, (2010: 123) pembiayaan bermasalah merupakan kredit yang telah disalurkan oleh bank, dan nasabah tidak dapat melakukan pembayaran atau melakukan angsuran sesuai dengan perjanjian yang telah ditandatangani oleh bank dan nasabah. Menurut Veithzal (2007: 478) faktorfaktor penyebab timbulnya pembiayaan bermasalah ini diantaranya adalah karena kesalahan pihak bank contohnya keyakinan yang berlebihan dan kurang pengecekan terhadap latar belakang debitur (nasabah), kemudian karena kesalahan debitur (nasabah) contohnya debitur (nasabah) tidak jujur dan nasabah serakah, dan selanjutnya karena faktor eksternal contohnya kondisi perekonomian dan bencana alam. Dari pendapat di atas dapat disimpulkan bahwa pihak bank harus mengambil keputusan pemberian kredit yang tepat agar terhindar dari resiko-resiko yang tidak terduga yang dapat merugikan bank.

Maka dari itu, untuk menghindari terjadinya resiko pembiayaan kredit bermasalah bank pada umumnya menerapkan beberapa prinsip kehati-hatian terhadap debitur (nasabah) diantaranya dengan berpedoman pada prinsip 5C (Character, Capital, Capacity, Collateral, Condition), (Kasmir, 2008: 108). Kemudian, melakukan analisis laporan keuangan debitur (nasabah). Menurut Munawir (2010: 35), analisis laporan keuangan adalah analisis laporan keuangan yang terdiri dari penelaahan atau mempelajari daripada hubungan dan tendensi atau kecenderungan (trend) untuk menentukan posisi keuangan dan hasil operasi serta perkembangan perusahaan yang bersangkutan. Menurut Kasmir (2012: 70) ada beberapa jenis teknik analisis laporan keuangan yang dapat dipakai salah satunya yaitu analisis rasio keuangan. Menurut James C. Van Horne dalam Kasmir (2012: 104) rasio keuangan merupakan indeks yang menghubungkan dua angka akuntansi dan diperoleh dengan membagi satu angka dengan angka lainnya. Rasio keuangan digunakan untuk mengevaluasi kondisi keuangan dan kinerja perusahaan.

Bank Bengkulu Cabang Tais seperti yang sudah ditetapkan dalam SK Direksi Nomor : 55/HP.00.02.04/D.4/2018 Tentang Kredit Modal Kerja dan Kredit Investasi. 2018. Bank Bengkulu Cabang Tais mempunyai perangkat aturan perkreditan yang jelas agar resiko pembiayaan kredit bermasalah dapat diminimalisir sebaik mungkin dan efektifitas pembiayaan kredit dapat tercapai. Walaupun demikian dalam kenyataannya masih ada kasus-kasus pembiayaan kredit bermasalah yang terjadi di Bank Bengkulu Cabang Tais. Dikarenakan, mayoritas debitur (nasabah) yang mendapatkan fasilitas pembiayaan kredit di Bank Bengkulu Cabang Tais mempunyai usaha dibidang Usaha Mikro Kecil dan Menengah (UMKM) seperti Petani Sawit dan Usaha Dagang yang belum memiliki catatan akuntansi yang baik dan benar seperti 
belum adanya laporan keuangan yang dapat menjadi salah satu alat analisa dalam pembiayaan kredit. Kemudian, juga diperparah dengan kondisi harga jual Tandan Buah Segar (TBS) kelapa sawit saat ini yang sangat rendah dan sulit diprediksi perubahannya. Hal tersebut membuat seluruh bidang usaha yang ada terkena dampaknya yang membuat menurunnya pendapatan usaha mereka dikarenakan daya beli dan daya bayar masyarakat menurun. Maka dari itu penerimaan atau pemasukan bank dalam pembiayaan kredit di Bank Bengkulu Cabang Tais mengalami penurunan dan banyak debitur (nasabah) yang tadinya kreditnya lancar menjadi macet.

Menurunnya penerimaan atau pemasukan Bank Bengkulu Cabang Tais dari pemberian kredit debitur (nasabah) memang bukan hanya karena salah perhitungan dalam analisis kredit sesungguhnya, namun faktor lain yang sulit dihitung dan diprediksi seperti kondisi harga jual Tandan Buah Segar (TBS) kelapa sawit yang sudah dijelaskan di atas atau adanya bencana alam bisa menjadi faktor perusak dalam pembiayaan kredit sehingga efektifitas pembiayaan kredit tidak tercapai. Namun, paling tidak apabila kredit telah dinilai sangat baik, resiko kredit macet dapat diminimalkan. Oleh sebab itu, sebelum kredit diberikan, wajib untuk terlebih dahulu dianalisis kelayakannya (Kasmir, 2014: 285). Dari penjelasan latar belakang di atas untuk itu dalam penelitian ini peneliti melakukan penelitian dengan judul "Peranan Analisis Laporan Keuangan dan Penilaian Prinsip 5C Terhadap Efektifitas Pemberian Kredit Pada PT. Bank Bengkulu Cabang Tais".

\section{TINJAUAN TEORETIS}

\section{Pengertian Laporan Keuangan}

Pengertian laporan keuangan menurut Ikatan Akuntan Indonesia dalam Standar Akuntansi Keuangan (SAK) (2009: 1) laporan keuangan meliputi bagian dari proses laporan keuangan. Laporan keuangan yang lengkap biasanya meliputi neraca, laporan laba rugi, laporan perubahan ekuitas, laporan perubahan posisi keuangan (yang dapat disajikan dalam berbagai cara misalnya, sebagai laporan arus kas/laporan arus dana), catatan dan laporan lain serta materi penjelasan yang merupakan bagian integral dari laporan keuangan.

\section{Analisis Laporan Keuangan}

Kasmir (2016: 66), mengemukakan analisis laporan keuangan bahwa agar laporan keuangan menjadi lebih berarti sehingga dapat dipahami dan dimengerti oleh berbagai pihak, maka perlu dilakukan analisis laporan keuangan. Hasil analisis laporan keuangan juga akan memberikan informasi tentang kelemahan dan kekuatan yang dimiliki perusahaan. Dengan adanya kelemahan dan kekuatan yang dimiliki, akan tergambar kinerja manajemen selama ini. Kemudian, Munawir (2010: 35) menjelaskan analisis laporan keuangan adalah analisis laporan keuangan yang terdiri dari penelaahan atau mempelajari dari pada hubungan dan tendensi atau kecenderungan (trend) untuk menentukan posisi keuangan dan hasil operasi serta perkembangan perusahaan yang bersangkutan. 


\section{Penilaian Prinsip 5C}

Menurut (Kasmir, 2012; Lisdiani, 2013), persetujuan pemberian kredit oleh bank kepada nasabah selalu mempertimbangkan prinsip 5C yang terdiri dari: Pertama, character. Lebih menekankan pada ukuran kemauan nasabah dalam memenuhi kewajibannya. Hal-hal yang berhubungan dengan prinsip Character ini dapat dilihat dengan meneliti riwayat hidup nasabah, reputasi calon debitur tersebut di lingkungan usaha, dan meminta informasi antar bank.

Kedua, capital. Capital sama-sama digunakan untuk melihat penggunaan modal apakah efektif, dilihat laporan keuangan (neraca dan laporan laba rugi) dengan melakukan pengukuran yang ditunjukkan melalui analisis angka rasio, seperti segi likuiditas, solvabilitas, rentabilitas, dan ukuran lainnya serta juga harus dilihat dari sumber mana saja modal yang ada sekarang ini.

Ketiga, capacity. Prinsip Capacity sama-sama melihat kemampuan debitur dalam menjalankan bisnis dalam bidang usahanya sehingga akan terlihat juga kemampuannya dalam mengembalikan kredit yang disalurkan. Hal-hal yang harus diperhatikan oleh bank antara lain melihat angka-angka hasil produksi, angka-angka penjualan dan pembelian, perhitungan laba rugi perusahaan saat ini dan proyeksinya, serta data-data keuangan diwaktu lalu yang terdapat pada laporan keuangan guna mengukur kemampuan calon debitur untuk melaksanakan rencana kerjanya di waktu yang akan datang.

Keempat, collateral. Prinsip Collateral merupakan jaminan yang diberikan calon nasabah baik yang bersifat fisik maupun non fisik. Jaminan hendaknya melebihi jumlah kredit yang diberikan. Jaminan juga harus diteliti keabsahannya sehinggga jika terjadi suatu masalah, maka jaminan yang dititipkan akan dapat dipergunakan secepat mungkin.

Kelima, condition. Condition dalam hal ini menilai kredit dari kondisi ekonomi dan politik sekarang dan dimasa yang akan datang sesuai sektor masing-masing, serta prospek usaha dari sektor yang dijalankan.

\section{Efektifitas Pemberian Kredit}

Efektifitas adalah suatu keadaan yang mengandung pengertian mengenai terjadinya suatu efek atau akibat yang dikehendaki. Kata efektif berarti terjadinya suatu efek atau akibat yang dikehendaki dalam suatu perbuatan. Setiap pekerjaan yang efektif belum tentu efisien, karena hasil dapat tercapai tetapi mungkin dengan penghamburan pikiran, tenaga, waktu, uang atau benda (Adisasmita, 2011: 170).

\section{METODE PENELITIAN}

Adapun jenis penelitian yang akan dilakukan oleh penulis dalam penelitian ini yaitu penelitian deskriptif dengan pendekatan kuantitatif dan kualitatif. Penelitian deskriptif kuantitatif diterapkan untuk menganalisis laporan keuangan debitur (nasabah) dengan analisis rasio keuangan yang dilakukan oleh petugas kredit bagian pemasaran dan kredit PT. Bank Bengkulu Cabang Tais dan menganalisis tingkat efektifitas pemberian kredit di PT. Bank Bengkulu Cabang Tais dengan melihat kemampuan debitur (nasabah) membayar angsuran kredit setiap bulan berdasarkan 
data dari periode tiga bulan terakhir (Agustus 2018 sampai dengan Oktober 2018) yang dimiliki oleh PT. Bank Bengkulu Cabang Tais. Sedangkan untuk penelitian deskriptif kualitatif diterapkan untuk menganalisis hasil penilaian prinsip 5C (Character, Capital, Capacity, Collateral, dan Condition) debitur (nasabah) berdasarkan hasil survey OTS (On The Spot) dan wawancara petugas kredit bagian pemasaran dan kredit PT. Bank Bengkulu Cabang Tais.

\section{PEMBAHASAN}

Pada variabel analisis laporan keuangan data yang didapat oleh peneliti berdasarkan contoh kasus pemberian kredit oleh PT. Bank Bengkulu dalam periode 3 (tiga) bulan terakhir. Analisis laporan keuangan ini menggunakan teknik analisis rasio keuangan yang digunakan oleh petugas kredit. Analisis ini dibuat berdasarkan hasil dari penilaian prinsip 5C debitur (nasabah) apabila hasilnya tidak layak maka analisis laporan keuangan ini tidak harus dibuat dan begitu juga sebaliknya. Ada 5 (lima) contoh kasus permohonan kredit berdasarkan variabel ini yang diterima dan ditolak oleh petugas kredit diantaranya sebagai berikut:

Tabel 1. Hasil Analisa Laporan Keuangan

\begin{tabular}{cccccccc}
\hline No & $\begin{array}{c}\text { Debitur } \\
\text { (Nasabah) }\end{array}$ & CR (\%) & DSCR (\%) & ROA (\%) & ROE (\%) & $\begin{array}{c}\text { DER } \\
\mathbf{( \% )}\end{array}$ & $\begin{array}{c}\text { Plafond } \\
\text { Kredit }\end{array}$ \\
\hline 1 & A & 0 & 0 & 34,8 & 39,1 & 25.2 & $100.000 .000,-$ \\
2 & B & 0 & 236,7 & 22,9 & 25,1 & 22,1 & $100.000 .000,-$ \\
3 & C & 0 & 251,2 & 23,2 & 22,8 & 10,0 & $100.000 .000,-$ \\
4 & D & 0 & 113,2 & 11,4 & 11,4 & 11,0 & $100.000 .000,-$ \\
5 & E & 0 & 449,6 & 21,2 & 26,6 & 0,39 & $100.000 .000,-$ \\
\hline
\end{tabular}

Sumber: PT Bank Bengkulu Cabang Tais, 2018

Pada variabel dalam penilaian prinsip 5C dari debitur (nasabah) yang didapat peneliti berdasarkan contoh kasus pemberian kredit oleh PT. Bank Bengkulu dalam periode 3 (tiga) bulan terakhir (Agustus 2018 sampai dengan Oktober 2018). Petugas kredit menilai prinsip 5C ini dengan melakukan survey OTS (On The Spot) dan wawancara terhadap debitur (nasabah) ditambah dengan pengecekan IDEB SLIK debitur (nasabah). Apabila hasil dari penilaian ini menunjukkan hasil yang tidak layak maka petugas kredit tidak harus membuat analisa laporan keuangan debitur (nasabah) karena hasil tersebut sudah cukup untuk bahan pertimbangan dalam menolak permohonan kredit debitur (nasabah) dan begitu juga sebaliknya. Ada 5 (lima) contoh kasus permohonan kredit berdasarkan variabel ini yang diterima dan ditolak oleh petugas kredit diantaranya sebagai berikut : 
Tabel 2. Hasil Penilaian Prinsip 5C

\begin{tabular}{ccccccc}
\hline \multirow{2}{*}{ No } & \multirow{2}{*}{ Debitur } & \multicolumn{5}{c}{ Penilaian Prinsip 5C } \\
\cline { 3 - 6 } & & Character & Capital & Capacity & Collateral & Condition \\
\hline 1 & A & Layak & Layak & Layak & Layak & Layak \\
2 & B & Tidak Layak & Tidak Layak & Tidak Layak & Tidak Layak & Tidak Layak \\
3 & C & Layak & Tidak Layak & Tidak Layak & Tidak Layak & Layak \\
4 & D & Tidak Layak & Tidak Layak & Tidak Layak & Layak & Layak \\
5 & E & Layak & Layak & Layak & Layak & Layak \\
\hline
\end{tabular}

Sumber: PT Bank Bengkulu Cabang Tais, 2018

\section{PENUTUP}

Dari hasil dan pembahasan dalam penelitian ini kesimpulan yang didapat diperoleh antara lain: Pertama, dari hasil penelitian menjelaskan bahwa analisis laporan keuangan yang dilakukan oleh petugas kredit PT. Bank Bengkulu Cabang Tais sudah sesuai prosedur ketentuan yang berlaku sehingga permohonan kredit yang diajukan benar-benar disaring dengan ketat.

Kedua, dari hasil penelitian menjelaskan bahwa penilaian prinsip 5C yang dilakukan oleh petugas kredit PT. Bank Bengkulu Cabang Tais sudah sesuai prosedur dan ketentuan yang berlaku sehingga permohonan kredit yang diajukan benar-benar disaring dengan ketat.

Ketiga, analisis laporan keuangan dan penilaian prinsip 5C sangat berperan penting dalam efektifitas pemberian kredit pada PT. Bank Bengkulu Cabang Tais. Walaupun dalam tingkat kemampuan bayar debitur (nasabah) rendah sehingga mengahasilkan kredit macet namun hal itu bukan karena analisis dan penilaian yang buruk tapi lebih disebabkan faktor lain yang sulit diprediksi yaitu kondisi perekonomian saat ini yang naik turun sehingga menyebabkan daya beli, daya jual, dan daya bayar menjadi rendah yang membuat debitur (nasabah) kurang lancar dalam membayar kreditnya.

\section{DAFTAR PUSTAKA}

Bank Bengkulu. 2018. Instruksi Direksi Bank Bengkulu, Nomor : 235/HP.00.01/D.4/2018 Tentang Ketentuan Suku Bunga Kredit.

Bank Bengkulu. 2018. Surat Keputusan Direksi, Nomor : 55/HP.00.02.04/D.4/2018 Tentang Kredit Modal Kerja dan Krdit Investasi.

Fahmi, Irham. 2012. Analisis Kinerja Keuangan. Alfabeta. Bandung. Hasibuan S.P,Malayu. 2008. Dasar-dasar Perbankan. PT. Grafindo. Jakarta.

Ikatan Akuntan Indonesia (IAI). 2009. Standar Akuntansi Keuangan Entitas Tanpa Akuntabilitas publik ( SAK ETAP). Dewan Standar Akuntansi Keuangan Ikatan Akuntan Indonesia. Jakarta.

Ismail. 2010. Manajemen Perbankan Edisi Pertama. Kencana. Jakarta.

Kasmir. 2012. Dasar-dasar Perbankan. Rajawali Pers. Jakarta. 
Kasmir, 2014. Analisis Laporan Keuangan, Edisi Pertama, Cetakan Ketujuh. PT. Rajagrafindo Persada. Jakarta.

Lumenta, Julia. 2015. Analisis Sistem Akuntansi Pembiayaan pada PT.Bank

Rakyat Indonesia (Persero) Tbk Kantor Cabang Pembantu Martadinata Manado.Tugas

Akhir, Jurusan Akuntansi Politeknik Negeri Manado, Pembimbing I : Jerry Sonny Lintong, SE.,MAP, Pembimbing II : Esrie A.N. Limpeleh, SE, MM

Mardiyatmo. 2008. Kewirausahaan. Yudhistira. Surakarta.

Munawir, S. 2010. Analisis laporan Keuangan Edisi Keempat Cetakan Kelima Belas. Liberty. Yogyakarta.

Mulyadi. 2013. Sistem Akuntansi Edisi 3. Salemba Empat. Jakarta.

Rival, Veithzal dan Arviyan Arifin. 2010. Islamic Banking. Bumi Aksara. Jakarta.

Supriyono. 2011. Akuntansi Biaya Pengumpulan Biaya dan Penentuan Harga Pokok Buku 1 Edisi 2. BPFE. Yogyakarta.

Undang-undang Nomor 7 tahun 1992 Tentang Perbankan

Undang-undang Perbankan Nomor 10 Tahun 1998 Pasal 1 Tentang Kredit 